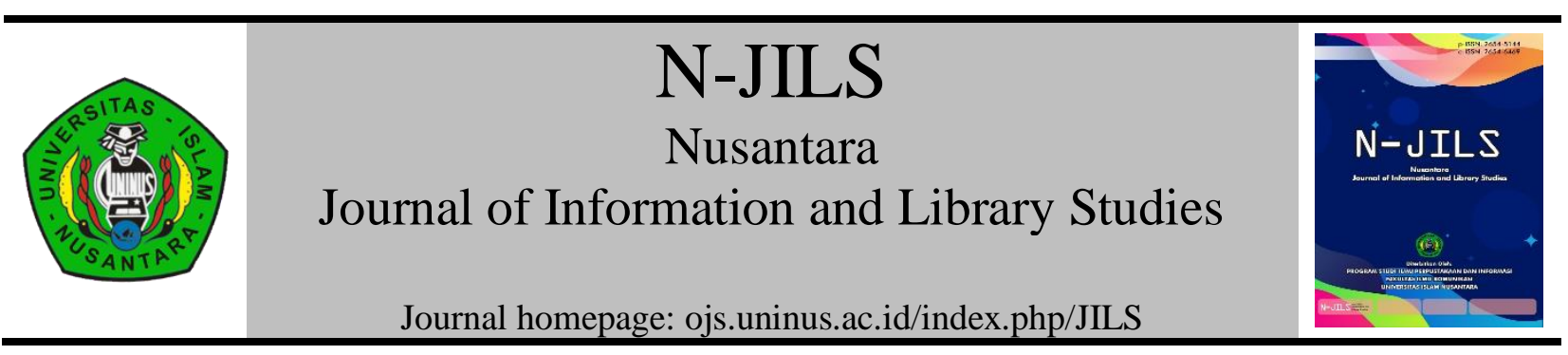

\title{
Kompetensi Literasi Informasi Pustakawan di Era Infodemik
}

\section{Librarian Information Literacy Competency in Infodemic Age}

\author{
Endang Fatmawati \\ Universitas Diponegoro \\ e-mail: endangfatmawati@live.undip.ac.id
}

\begin{tabular}{ll}
\hline ARTICLE INFO & ABSTRACT \\
\hline Article history & The purpose of writing is to bring up creative librarian \\
Received [October, 2020] & ideas and provide problem-solving strategies related to the \\
Revised [November, 2020] & circulation of hoax in the infodemic era. The discussion \\
Accepted [December, 2020] & uses the literature review method related to infodemics, \\
Available Online [December, 2020] & information literacy competencies, and librarian strategies \\
& in the social media era. High rapid social media and \\
& internet access users are not accompanied by literacy \\
& competencies. One of the efforts to build a knowledge \\
& ecosystem is through increasing information literacy \\
competencies. In the context of libraries, social media & influences the relationships and social interactions carried \\
out by librarians. The wave of information that is not \\
necessarily accurate is increasingly being spread through \\
social media. Library information sources can be \\
disseminated through social media applications with \\
various platforms. His practice in the library is building \\
scientific communication, knowledge management, \\
promotion, marketing, and publication. Due to the rapid \\
dissemination of information, librarians are expected to \\
have the sensitivity and expertise in packaging information, \\
disseminating it through social media, cleverly sorting and \\
choosing, and wisely using it. The problem-solving strategy \\
that exists in the era of social media for librarians to be \\
able to surf the internet is healthy information literacy \\
competence.
\end{tabular}

Keyword: information literacy; librarian competence; hoax; infodemic; social media 
Kata kunci: literasi informasi; kompetensi pustakawan; hoaks; infodemik; media sosial

\begin{abstract}
ABSTRAK
Tujuan penulisan untuk memunculkan gagasan kreatif pustakawan dan memberikan strategi pemecahan masalah terkait dengan beredarnya informasi hoaks di era infodemik. Metode kajian menggunakan metode kajian pustaka terkait dengan infodemik dalam era media sosial, kompetensi literasi informasi, serta strategi pustakawan di era media sosial. Tingginya akses internet dan pesatnya pengguna aktif media sosial tidak dibarengi dengan kompetensi literasi. Padahal salah satu upaya membangun ekosistem pengetahuan adalah melalui peningkatan kompetensi literasi informasi. Dalam konteks perpustakaan, media sosial berpengaruh pada relasi dan cara berinteraksi sosial yang dilakukan oleh pustakawan. Gelombang informasi yang belum tentu akurat semakin terasa masif penyebarannya melalui media sosial. Sumber informasi perpustakaan dapat didesiminasikan melalui aplikasi media sosial dengan berbagai platform. Praktiknya di perpustakaan adalah membangun komunikasi ilmiah, pengelolaan pengetahuan, promosi, pemasaran, serta publikasi. Oleh karena penyebaran informasi demikian pesat, maka pustakawan diharapkan memiliki kepekaan dan kepiawaian dalam mengemas informasi, menyebarkan melalui media sosial, cerdas memilah dan memilih, maupun bijak dalam menggunakannya. Strategi pemecahan masalah yang ada di era media sosial bagi pustakawan agar dapat berinternet sehat adalah memiliki kompetensi literasi informasi.
\end{abstract}

(C) 2020 NJILS. All rights reserved.

\section{A. PENDAHULUAN}

Pustakawan bisa berperan luas sebagai pegiat literasi. Terlebih dengan hadirnya media baru yang ditandai dengan akses informasi yang begitu mudah dan sangat cepat. Sekilas memang tidak ada hubungannya antara profesi pustakawan dengan informasi hoaks yang beredar di internet. Sekalipun ketentuannya tidak ada dalam aturan tugas pokok dan fungsi (tupoksi) dan perundangan, tetapi pustakawan setidaknya memiliki tanggung jawab moral dalam memberikan pendidikan pemustaka.

Internet sebagai media baru bagaikan "man behind the gun”. Hal ini mengandung arti bahwa ada dampak positif dan negatif yang ditimbulkan. Kementerian Komunikasi dan Informatika mencatat 554 hoaks selama bulan Januari s.d. April 2020 di berbagai panggung digital. Selanjutnya 301 hoaks diantaranya tentang Covid-19 (Paramita, 2020). Masifnya penyebaran informasi hoaks di media sosial seiring dengan tumbuh pesatnya pengguna smartphone berbasis Android, iOS, maupun Windows. Beberapa isu yang muncul tidak hanya terkait dengan informasi yang menyesatkan akibat, pencegahan, dan penanganan Covid-19 saja, tetapi juga infodemik. Kominfo juga mencatat bahwa hingga 5 Mei 2020 
telah ditemukan 1401 sebaran isu hoaks dan disinformasi dari Covid-19 yang telah tersiar di masyarakat.

Era media sosial membuat setiap orang semakin mudah mendapatkan informasi, dapat melakukan apa saja, memproduksi dan mengkonsumsi informasi, maupun menyebarkan informasi secara luas. Hal ini jelas berdampak pada komunikasi virtual tanpa batas sehingga harus disadari bahwa dunia terasa ada dalam genggaman kita. Fenomena munculnya hoaks dan berita yang dibangun tidak berdasarkan fakta (fake news), telah menjadi hiasan dalam era media sosial. Sebagai contoh saat pandemi Covid-19 adalah fenomena infodemik. Dampak munculnya information pandemic (infodemic) adalah juga sama berbahayanya dengan virusnya sendiri. Infodemik menjadi wabah informasi yang sengaja diproduksi oleh oknum tertentu dan disebarkan dengan motif tertentu. Hal ini terkait dengan informasi yang berlebihan terkait Covid-19 dan belum tentu isi informasinya valid. Masyarakat akhirnya merasa panik, takut, maupun khawatir yang berlebihan, padahal informasinya belum tentu benar. Bahaya infodemik akan semakin mengerikan di tengah akses internet yang murah dan mudah. Contoh sederhana banyaknya WhatsApp Group (WAG) yang dimiliki pustakawan, sehingga bisa jadi ada kesamaan informasi yang diperoleh dari WAG satu dengan WAG lainnya. Informasi sampah menjadi banyak, begitu pula informasi yang isinya hanya berita bohong (hoax) semakin mudah masuk di ponsel kita. Belum lagi oleh setiap anggota WAG yang bisa bebas mengunggah informasi. Dengan demikian, semakin besar pula peluang tersebarnya infodemik Covid-19.

Adanya tsunami informasi saat ini menyebabkan berita yang hadir menjadi tidak terbendung lagi, sehingga seharusnya membutuhkan kompetensi literasi informasi masyarakatnya. Pustakawan sebagai bagian dari masyarakat bisa mengambil peran untuk berkontribusi luas dalam mengedukasi pemustaka. Hal ini karena pustakawan sebagai unsur utama dalam mengelola informasi dan bertanggung jawab atas keluar masuknya informasi di perpustakaan. Wujud konkritnya harus ada ketegasan setiap individu dalam berinternet maupun wajib berhati-hati dengan lebih selektif dalam mengkonsumsi dan menyebarkan informasi yang terus hadir berkelindan di media sosial.

Oleh karena sedemikian berpengaruhnya peran pustakawan dalam melawan hoaks di era media sosial, maka membutuhkan gagasan kreatif sebagai strategi yang solutif. Identifikasi masalahnya antara lain: maraknya infodemik Covid-19, hoaks, dan fake news dalam berbagai platform yang mewarnai media sosial sehingga meresahkan masyarakat; 
banyaknya informasi yang tidak jelas kredibilitas dan kebenarannya maupun meragukan sumbernya; ada sebagian masyarakat yang bersikap kritis bukan pada fakta tetapi sekedar mempertahankan keyakinannya saja; pemustaka belum semuanya memiliki kepiawaian dalam menyaring, memilih, memilah, maupun mengevaluasi informasi secara cerdas; serta ada sebagian pustakawan yang masih terjebak berkutat pada rutinitas pekerjaan yang bersifat teknis sehingga belum mampu berperan luas maupun berkontribusi dalam mengedukasi masyarakat terkait melawan hoaks. Tujuan kajian dalam artikel adalah untuk memunculkan gagasan kreatif pustakawan dan memberikan strategi pemecahan masalah terkait dengan beredarnya informasi hoaks dan infodemik di era media sosial.

\section{B. TINJAUAN PUSTAKA}

Shao \& Purpur (2016) dalam kajiannya terkait dampak keterampilan literasi informasi bahwa literasi informasi menjadi salah satu keterampilan berpikir tingkat tinggi untuk mendukung suksesnya akademis, profesional, dan pribadi. Selanjutnya terkait pandemi Covid-19, bahwa kenyataannya masyarakat tidak hanya melawan pandemi tetapi juga infodemik dari Covid-19. Cinelli et al. (2020) meneliti infodemik Covid-19 di media sosial Gab, Reddit, YouTube, Instagram, serta Twitter. Dari hasil analisis komparatif pada kelima platform media sosial dikatakan dalam kondisi health emergency.

Selanjutnya Eysenbach (2020) menjelaskan empat pilar untuk melawan infodemik, yaitu: pemantauan informasi (infoveillance), membangun literasi eHealth dan kapasitas literasi sains, mendorong peningkatan pengetahuan dan proses peningkatan kualitas, maupun akurasi dan translasi pengetahuan secara tepat termasuk meminimalkan faktor-faktor yang menyimpang seperti pengaruh politik dan komersial. Sejauh ini dari kajian literatur terdahulu, belum ada yang khusus membahas kompetensi literasi informasi pustakawan pada era infodemik sehingga hal ini menjadi aspek kebaruan ilmiah dari pembahasan. Artikel ini membahas tentang kompetensi literasi informasi pustakawan di era infodemik.

\section{METODE PENELITIAN}

Metode penelitian yang digunakan dengan studi kepustakaan (library research). Penulis melakukannya dengan kajian pustaka terhadap literatur terkait dengan masalah yang dibahas. Hal ini terkait dengan infodemik dalam masa pandemi Covid-19, kompetensi literasi informasi, serta strategi pustakawan di era infodemik. Sumber pustaka yang 
digunakan berupa literatur dan data sekunder. Prosedur yang dilakukan dengan cara menelaah kritis literatur yang ada dikaitkan dengan fenomena yang terjadi di lapangan untuk disampaikan kepada khalayak khususnya bagi profesi pustakawan. Untuk pengambilan data dilakukan dengan telaah pustaka, dan hasilnya dijelaskan dalam pembahasan dengan mengacu pada korpus kompetensi literasi informasi pustakawan di era infodemik.

\section{HASIL DAN PEMBAHASAN}

\section{Infodemik Dalam Era Media Sosial}

Selama wabah pandemi non alam Covid-19, ada peningkatan perilaku masyarakat dalam menggunakan internet untuk berkomunikasi maupun bertransaksi online. Infodemik merupakan kondisi berkembangnya informasi terkait suatu fenomena tanpa mempertimbangkan unsur kebenaran data dan fakta. Infodemik sudah mengglobal dan kemunculannya justru mengganggu usaha pencarian solusi terhadap masalah Covid-19, sehingga memunculkan persoalan kekhawatiran atau kepanikan masyarakat. Penulis berpendapat bahwa dalam konteks di Indonesia, tingginya jumlah pengguna internet itu turut berpengaruh dan mendukung jumlah pengguna media sosial (Fatmawati, 2017, 2018). Saat wabah pandemi Covid-19 melanda, kita semua tidak dihadapkan pada persoalan memerangi pandemi, tetapi juga melawan infodemik (infodemic) Covid-19. Fenomena yang ada bahwa infodemik juga berjangkit bersama dengan virus coronanya. WHO (2020) menggambarkan wabah dan respons terhadap Covid-19 telah disertai dengan infodemik besar-besaran dan kelimpahan informasi yang berlebihan (an over-abundance of information) dan kadang akurat dan kadang tidak (some accurate and some not).

Cakupan infodemik Covid-19 yang beredar sangat variatif dan banyak sekali, baik terkait pencegahan, penanganan, vaksin, penularan, serta yang lainnya. Salah satu contoh infodemik, pernah beredar informasi melalui WhatsApp terkait thermo gun yang berbahaya bagi otak dan hal ini sungguh mengkhawatirkan masyarakat. Rasa takut dan bingung muncul dalam pikiran yang menerima video infodemik yang konten pesannya bohong (hoaks) dan tidak benar. Padahal informasi yang betul bahwa thermo gun sudah jelas lolos uji kesehatan dan aman digunakan.

Serangan infodemik di era media sosial di tengah suasana pandemi Covid-19 sungguh berbahaya. Akibat infodemik membuat masyarakat timbul rasa cemas yang berlebihan dan mungkin menjadi tidak percaya pada tenaga medis, pemerintah, dan bahkan 
ilmu pengetahuan. Kepercayaan masyarakat menjadi terkikis karena infodemik yang beredar di belantara internet dan media sosial. Akhirnya "matinya kepakaran" memang terjadi di Indonesia, karena masyarakat lebih percaya pada informasi yang beredar, dan mudah percaya dengan informasi yang sama dengan pemikirannya. Akhirnya hoaks dianggap suatu kebenaran hanya karena informasi yang bergema di media sosial sehingga terjadi segregasi digital. Informasi sampah sangat masif, mulai dari tulisan di blog, teori konspirasi, sampai dengan infodemik yang isinya hoaks belaka. Jika Nichols (2017) mengulas dalam konteks di Amerika, tetapi hal itu cocok dengan keadaan Indonesia di era media sosial ini.

Media sosial menciptakan komoditas, begitu juga hoaks yang dipastikan ada kepentingan ekonomi politik di balik itu. Hoaks ada di mana-mana dan semua orang berpeluang menyebarkannya. Istilah kelimpahan (abundance) memang terjadi di era media sosial dimana informasi berbagai bidang disiplin ilmu berlimpah ruah. Indikator keberlimpahan adalah free ekonomi yang praktiknya semua gratis, berlimpah, dan berbiaya murah, misalnya: email gratis, telepon via WA gratis, YouTube gratis, webinar gratis, buku gratis, dan lain sebagainya. Harus disadari bahwa teknologi telah menciptakan teknofilantropis. Kondisi yang demikian seperti ulasan yang dikemukakan oleh Diamandis dan Kotler (2012) terkait free economy.

Jika mengamati persoalan yang ada dikaitkan dengan teori yang relevan bahwa pesatnya perkembangan media sosial di Indonesia menjadi hal yang menarik untuk dibahas. Saat ini, semua orang seperti memiliki medianya sendiri. Media berarti sebagai sarana atau perantara, penghubung, dan alat komunikasi, sedangkan sosial terkait pada masyarakat atau merujuk pada bagaimana caranya orang melakukan interaksi. Carey dalam Lievrouw and Livingstone (2006) memaparkan bahwa interaktivitas pada media baru adalah teknologi yang menyediakan komunikasi "person to person" dan interaksi "person to machine". Selanjutnya media sosial menurut pandangan Kaplan \& Haenlein (2010) merupakan aplikasi yang basisnya internet sehingga pengguna dapat menciptakan maupun bertukar konten.

Jadi dalam ranah perpustakaan sangat memungkinkan setiap pustakawan dan pemustaka dapat merepresentasikan dirinya dan perpustakaannya melalui media sosial. Hal ini seperti bagaimana melakukan interaksi, berjejaring, bekerja sama, saling berbagi, berkomunikasi, maupun membentuk ikatan sosial yang semuanya dilakukan secara virtual. Seiring berkembangnya TIK, maka informasi yang beredar menjadi semakin tak terkendali. Indonesia termasuk sepuluh besar negara yang paling lama mengakses internet dan adiktif 
media sosial. Apabila dilihat dari waktunya untuk akses, diketahui bahwa penggunanya menghabiskan waktu yang berbeda-beda. Data di Indonesia terkait tren waktu mengakses seperti pada Lampiran 1.

Dari Lampiran 1 tampak bahwa rata-rata durasi mengakses internet setiap hari yaitu 7 jam 59 menit melalui perangkat apa pun. Sementara itu, rata-rata waktu yang dibutuhkan ketika bermedia sosial yaitu 3 jam 16 menit per hari. Sebagaimana data terkait tren internet dan media sosial, dijelaskan bahwa dari total populasi jumlah penduduk Indonesia yang 272,1 juta, ternyata jumlah pengguna internetnya sebesar 175,4 juta jiwa. Selanjutnya sebanyak 388,2 juta ponsel beredar di masyarakat Indonesia dan pemakai media sosial aktif 160 juta orang.

Perkembangan media sosial menyebabkan informasi berkembang dengan lebih cepat dan mudah didapat oleh siapa pun. Bahkan kecenderungan untuk update informasi dapat dilakukan dimanapun dan kapanpun. Media sosial memiliki jangkauan global dan menjadi alat multidimensi untuk berbagi pengetahuan. Secara umum media baru memiliki ciri, antara lain: interaktif, hipertekstual, jaringan, maya atau virtual, simulasi, maupun digital. Selanjutnya Mayfield (2008) menyebutkan karakteristik media sosial seperti: partisipasi, keterbukaan, percakapan, komunitas, maupun keterhubungan.

Harus disadari jika pustakawan dan masyarakat secara umum sebetulnya telah mengalami fenomena yang disebut dengan istilah gegar budaya (culture shock) media sosial. Artinya terbiasa membaca berita dengan sepotong-potong maupun dengan model instan, kemudian berperilaku gegabah segera melakukan share, forward, dan lain sebagainya. Bahkan karena instannya maka mereka tidak sempat memikirkan dan mengendapkan dahulu isi pesannya maupun mengklarifikasi kebenaran informasinya. Padahal seharusnya melakukan konfirmasi (tabayyun) terlebih dahulu terhadap data informasi yang diterima dan jika sudah benar maka baru disebarkan.

Era media sosial saat ini telah menggeser Word of Mouth (WOM) yang dahulu dilakukan secara bertatap muka secara fisik menjadi elektronik WOM (eWOM). Hadirnya media baru internet menjadi evolusi proses komunikasi tradisional dengan tatap muka fisik menjadi cyberspace, sehingga jika meminjam istilah dari Thurau, TH., et al. (2004) bahwa eWOM communication menjadi media untuk "gethok tular daring". Media sosial dapat memberikan kesempatan untuk berbagi saran pribadi terkait apa yang mereka konsumsi secara virtual. Jika meminjam definisi media sosial yang disampaikan oleh Wasike (2013) 
yaitu sebagai instrumen multidimensional untuk berdiskusi dengan orang lain dan berkomunikasi dalam rangka berbagi pengetahuan dengan berbagai macam disiplin ilmu.

Media sosial juga membuat suatu era yang disebut era "post-truth". Konsep posttruth sebagaimana dikenalkan oleh Keyes (2004), karena media sosial telah beralih fungsi seolah-olah sebagai penyampai kebenaran. Padahal tidak selamanya demikian, justru yang menjadi persoalan karena ada orang yang menjadi penyebar kebohongan atau ketidakbenaran. Jadi pada titik ini, kebohongan yang muncul karena suatu kesengajaan oknum yang melakukan proliferasi dan viralisasi informasi hoax dan fake news. Proliferasi dalam konteks ini, berarti aktivitas menyebarluaskan informasi dengan sangat cepat, sedangkan viralisasi berarti bersifat menyebarkan secara luas. Kedua hal ini dilakukan baik dengan sengaja didesain ataupun murni terjadi alami di kalangan pemustaka sebagai bagian dari masyarakat luas.

Konten media sosial yang menampilkan berbagai narasi yang tidak sesuai dengan subjek dan objek, berbagai informasi gambar yang menyesatkan, maupun video yang belum tentu teruji kebenarannya, jelas menuntut rekonstruksi peran para pustakawan kekinian. Hal ini untuk bisa menelaah isu-isu yang terjadi dengan melakukan konfirmasi kebenaran dari informasi yang ada. Solusi bijak dalam bermedia sosial adalah dengan mengklarifikasi terlebih dahulu sebelum menyebarkan dan berkomentar.

Kini jumlah konvergensi informasi yang membanjiri di pelbagai kanal gawai pemustaka semakin masif. Inilah mengapa era media sosial juga sebagai era digital. Artinya kondisi dalam era media sosial sering dianggap sebagai telekomunikasi internet yang menyimpan berbagai informasi dalam bentuk basis data yang besar. Senada dengan yang dikemukakan oleh Hilbert (2012) bahwa era digital sering dianggap identik dengan telekomunikasi internet dan mobile phones, dengan penyimpanan informasi yang besar dan pangkalan data.

\section{Kompetensi Literasi Informasi}

Era media sosial menyebabkan tingkat kecanduan penggunanya sangat tinggi. Dalam memberikan strategi pemecahan masalah terkait dengan permasalahan, maka wajib bagi pustakawan untuk memiliki kompetensi literasi informasi. Kompetensi dalam Keputusan Menteri Tenaga Kerja dan Transmigrasi RI Nomor 83 Tahun 2012 (Perpustakaan Nasional, 2012), dijelaskan bahwa: 
"Kompetensi adalah kemampuan seseorang yang mencakup pengetahuan, keterampilan dan sikap kerja yang dapat terobservasi dalam menyelesaikan suatu pekerjaan atau tugas sesuai dengan standar kinerja yang ditetapkan”.

Selanjutnya dalam Keputusan Menteri Ketenagakerjaan Republik Indonesia Nomor 236 Tahun 2019, disebutkan bahwa secara etimologi:

"Kompetensi adalah suatu kemampuan yang dibutuhkan untuk melakukan atau melaksanakan pekerjaan yang dilandasi oleh pengetahuan, keterampilan dan sikap kerja, sehingga dapat dirumuskan bahwa kompetensi diartikan sebagai kemampuan seseorang yang dapat terobsesi mencakup atas pengetahuan, keterampilan dan sikap kerja dalam menyelesaikan suatu pekerjaan atau tugas sesuai dengan standar performa yang ditetapkan".

Jadi jika dianalogikan dalam konteks ini dapat dikatakan bahwa kompetensi literasi informasi pustakawan berarti pustakawan memiliki kemampuan memproduksi, menciptakan, mengkomunikasikan, kemudian secara aktif dapat merespon, serta mengevaluasi berbagai informasi yang diterima secara kritis. Hubungan kompetensi literasi informasi dengan pemahaman penggunaan media sosial, bahwa pustakawan sangat perlu memiliki kompetensi literasi informasi, sebagai upaya agar pustakawan memiliki pemahaman yang cukup terkait penggunaan media sosial secara bijak. Upaya ini diharapkan agar tercipta pustakawan yang literated. Caranya dengan mengoptimalkan dampak positif maupun meminimalisir dampak negatif dari penggunaan internet.

Meminjam istilah yang pernah dikemukakan oleh Castiglione, Deth, \& Wolleb (2008), maka penulis berpendapat bahwa media sosial menjadi semacam "kapital sosial" juga bagi pemakainya untuk berinteraksi dan membangun jejaring. Kapital sosial menjadi sumber daya yang termuat di dalam suatu relasi sosial dan memiliki fungsi produktif, yaitu memungkinkan pustakawan untuk mencapai hasil yang sulit mereka peroleh tanpa kehadiran sumber daya media sosial tersebut. Bahkan Tzanakis (2013) menggambarkan kapital sosial sebagai efek dan konsekuensi dari pergaulan maupun keterhubungan manusia, serta hubungannya dengan individu dan juga struktur sosialnya.

Ada berbagai istilah yang konsep dasarnya berbeda, seperti media sosial, media online, jejaring sosial, maupun website/situs web. Lebih jelasnya penulis ilustrasikan dalam Lampiran 2. Perpustakaan melalui pustakawannya harus menjadi gerbang informasi sehat yang mencerdaskan dengan memaksimalkan pemanfaatannya. Pustakawan harus mampu menangkap peluang adanya media sosial sehingga bukan hal yang sulit jika informasi di perpustakaan bisa dikomunikasikan kepada pemustaka. 
Pendapat penulis terkait dengan strategi kunci yang sekiranya bisa ditempuh untuk mendukung kompetensi pustakawan dalam era media sosial, antara lain: Pertama, pustakawan harus terus belajar untuk menyesuaikan dengan kondisi (update) dan menaikkan (upgrade) dari kompetensi yang dimiliki. Pustakawan harus berkelanjutan dalam memahami kebutuhan pemustaka milenial dengan menghadirkan informasi yang dikemas dalam platform gaya milenial berbasis media sosial, misalnya: YouTube, Instagram, Vlog, dan yang lainnya. Kedua, pustakawan perlu memiliki literasi media sosial sebagai solusi bijak mengatasi gegar budaya digital. Artinya pustakawan memiliki pengetahuan, keterampilan, dan pemahaman tentang tata cara bagaimana menggunakan media sosial yang baik, sehingga dapat bersikap lebih selektif dalam mendistribusikan konten ke dunia virtual yang notabene menjadi ranah publik.

Ketiga, pustakawan akan lebih kompeten jika memiliki critical thinking dalam memproduksi, mengemas, dan mengkonsumsi informasi. Pustakawan sebagai motor perubahan bangsa harus well informed mulai dari mengidentifikasi, mengeksplorasi, menyeleksi, mengenali karakteristik informasi hoax, memverifikasi, sampai dengan menerapkan informasi yang diperoleh. Keempat, pustakawan harus selalu meningkatkan multi-kompetensi dengan mengasah pengetahuan, keterampilan, dan sikap. Disamping memiliki kepakaran dalam bidang perpustakaan, pustakawan dalam era media sosial saat ini membutuhkan kompetensi lainnya yang mendukung profesinya, misalnya: literasi komputer, literasi digital, literasi internet, literasi media, repackaging informasi, dan lain sebagainya.

Kelima, pustakawan harus menangkap peluang media sosial dari sisi positifnya. Hal ini misalnya sebagai media information sharing dan media promosi online terkait perpustakaannya. Melalui media sosial, pustakawan juga bisa membangun brand diri melalui personal branding. Keenam, pustakawan harus berprinsip "thinking before clicking". Artinya berpikir dahulu sebelum menyentuh tombol share, lebih ekstra hati-hati dalam menggunakan media sosial, dan lebih selektif sebelum membagikan konten apapun bentuknya ke media sosial.

Sulitnya pengawasan konten yang tersebar di media sosial maka membutuhkan kompetensi literasi informasi dari setiap individu. Sehubungan dengan bahasan kompetensi literasi informasi yang harus dimiliki oleh pustakawan, maka pustakawan wajib memiliki kemampuan teknikal dalam mengakses internet. Selain itu, pustakawan juga kritis memahami informasi yang diakses, sehingga tidak langsung menerima saja tetapi perlu lebih 
selektif menganalisis tingkat keakuratannya. Pemahaman kritikal mengisyaratkan adanya proses kognitif, artinya berkaitan dengan kemampuan analitik, yaitu kesadaran untuk memahami konten, fungsi dan evaluasi konten yang diperoleh dari internet. Pada tahap pemahaman kritikal ini, maka pustakawan dituntut memiliki kompetensi yang tidak hanya kritis pada permukaannya saja melainkan juga pada isi informasinya.

\section{Strategi Pustakawan di Era Media Sosial}

Pustakawan harus bangkit dan menyadari jika media sosial tidak selamanya berdampak negatif. Namun harus mengambil sisi peluangnya bahwa jika perpustakaan bisa memanfaatkannya maka justru menjadi kekuatan positif yang luar biasa efeknya. Keanekaragaman sumber informasi yang dimiliki oleh perpustakaan dapat disampaikan dengan status, informasi review buku terbaru, foto event perpustakaan, e-resources yang dilanggan, maupun data bibliografis koleksi. Suatu contoh bagi pustakawan kreatif adalah memanfaatkan aplikasi FB, Instagram, Twitter, YouTube, dan aplikasi media sosial lainnya. Untuk meningkatkan kompetensi, maka pustakawan era media sosial juga dituntut kompeten berperan sebagai blogger dan youtuber. Tuntutan ini untuk mengakomodir pemustaka generasi milenial yang lekat dengan aktivitas berbasis digital.

Kemas ulang informasi perpustakaan dalam bentuk vlog menjadi tren di era media sosial. Jadi jelas dibutuhkan kompetensi untuk adaptif dengan media baru. Selain itu, pustakawan di era media sosial juga dituntut kompeten menjadi vlogger dengan membuat blog video ( $v \log$ ) untuk membuat konten informasi yang berkualitas, baik dengan cara berbicara dengan menampilkan diri (talking head), memberikan tutorial (how-to), maupun dengan merekam aktivitas yang panjang (reality). Hal ini senada dengan pandangan Dickson dan Holley (2010) yang menjelaskan pentingnya sikap proaktif dan partisipasi aktif pustakawan pada jejaring sosial.

Informasi yang dimiliki perpustakaan, misalnya koleksi perpustakaan terbaru, bisa dipromosikan dan dikenalkan dengan mengemas ulang informasinya dalam bentuk vlog tersebut. Kegiatan ini tentu menjadi peluang bagi pustakawan milenial untuk lebih mengenal lebih dekat dengan kebutuhan informasi pemustaka milenial. Pustakawan vlogger bisa menyematkan video ke dalam sebuah postingan maupun mengunggah secara langsung dalam saluran media sosial via YouTube. Jika melihat pada penelitian Xie \& Stevenson (2014) bahwa ada aspek yang digunakan dalam aplikasi media sosial untuk perpustakaan 
digital. Hal ini meliputi aspek jenisnya, penempatannya, pembaharuannya, maupun jenis interaksinya dan perannya.

Pustakawan sangat perlu untuk menjaga dan mengendalikan lisan ketika berbicara di media sosial. Dalam bermedia sosial seharusnya memperhatikan beberapa hal, yaitu, pertama, mencari fakta dan bukti, dengan bersikap kritis ketika menerima informasi. Harus berprinsip mengutamakan kebenaran daripada kecepatan (being right above being first). Kedua, memilih informasi dengan ekstra hati-hati, termasuk saat akan membagikan, menyukai, maupun meneruskan ke orang lain. Ketiga, memperhatikan etika berinformasi untuk menghindari plagiasi. Hal ini dilakukan dengan mencantumkan sumbernya jika mengutip dan jangan diakui sebagai pendapatnya sendiri. Keempat, tidak berbicara, memposting, mengunggah dan memberikan konten yang memiliki unsur pelecehan SARA dan mengandung unsur hoax, fake news, dan hate speech. Termasuk juga tidak iseng merespon email di spam yang link pengirimnya tidak dikenal spam. Kelima, mengelola (laptop, komputer, smartphone) dengan memberikan filter agar tidak bisa mengakses konten ilegal maupun situs tidak sehat seperti pornografi, perjudian, rasisme, dan konten negatif lainnya yang merusak moral. Keenam, tidak sembarang memberikan komentar yang bernada kebencian, permusuhan, dan provokasi di akun orang lain. Jika emosi dan asal bicara maka bisa melanggar Undang-Undang tentang ITE dan terkena hukuman. Dalam konteks ini lebih baik berbicara yang baik atau memilih diam saja. Ketujuh, mengupayakan untuk melawan hoaks dengan tanpa mengganggu kebebasan berpendapat dan berekspresi di media sosial. Hal ini misalnya untuk WAG hendaknya pustakawan fokus dengan berprinsip menjalin silaturahmi. Kedelapan, memasang aplikasi khusus di komputer untuk mencegah konten negatif, misalnya: parental control dan yang lainnya. Kesembilan, tidak memposting hal-hal yang bersifat personal di media sosial yang sekiranya menjadi celah bagi oknum yang nantinya merugikan diri kita. Hal ini seperti foto, data keluarga, alamat dan nomor telepon, maupun yang lainnya. Kesepuluh, menelaah informasi yang diperoleh dengan nalar sehingga lebih selektif dalam memberikan informasi. Hal ini dilakukan dengan mengecek kembali dengan seksama kebenaran informasi yang beredar di internet dan menelusur sumbernya. Kesebela, memerlukan literasi digital dalam mensosialisasikan praktik komunikasi digital yang aman maupun risiko dari aktivitas online yang telah dilakukan. Literasi digital menurut Casey and Bruce (2011) merupakan kemampuan menggunakan, memahami, mengevaluasi dan menganalisis informasi dalam berbagai format dari berbagai macam sumber digital. 
Kedua belas, cerdas dalam memilih dan menyaring teman-teman yang ada dalam jaringan virtual media sosial dan tidak asal mengkonfirmasi, sehingga menghalau kejahatan yang barangkali tersembunyi. Ketiga belas, menguji hoaks dan infodemik Covid-19 dengan mengkonfirmasi kebenarannya pada situs resmi Kemkominfo, turn back hoax, bertanya melalui media tools fact checking (Google Reverse Image dan Kalimasada Mafindo), dan yang lainnya.

Dalam konteks perpustakaan, sisi positif dari media sosial dapat diaplikasikan untuk kepentingan membangun jejaring dan promosi perpustakaan sehingga jangkauannya lebih luas. Pemanfaatan media sosial di perpustakaan bisa membangun ekosistem pengetahuan sampai dengan meningkatkan jaringan komunikasi ilmiah. Untuk merealisasikannya maka suatu hal yang tidak boleh ditawar yaitu kompetensi literasi informasi pustakawan. Pustakawan tidak cukup hanya menguasai hardware maupun software saja, tetapi juga harus memiliki kemampuan untuk berpikir secara kritis dalam mengevaluasi informasi, maupun memiliki kemampuan untuk menyadari dan memahami aturan-aturan yang terdapat dalam dunia digital (Lankshear \& Knobel, 2008).

Beberapa contoh strategi konkrit pustakawan yang ingin penulis sampaikan dalam upaya mewujudkan internet sehat di era media sosial, antara lain: Pertama, gethok tular daring. Pustakawan dapat berpartisipasi aktif melalui akun media sosial perpustakaan. Kegiatan diseminasi informasi ini misalnya: koleksi terbaru, pedoman akses e-resources, denda keterlambatan, jam buka layanan, ask librarian, dan lain sebagainya. Melalui gethok tular daring ini, antar pustakawan dan pemustaka tidak perlu bertatap muka secara langsung sebagaimana layanan tradisional. Raacke (2008) menjelaskan bahwa situs jejaring sosial berkaitan erat dengan gethok tular daring karena pengguna dapat dengan bebas membagi pengalaman dan opininya kemudian menyebarkannya dengan cepat dalam jaringan sosial.

Kedua, membangun jejaring sosial dan Sosialisasi Internet Sehat dan Aman (INSAN) sehingga dengan memiliki kompetensi literasi informasi maka pustakawan bisa lebih profesional dalam melakukan kegiatan sosialisasi melalui pembelajaran etika berinternet secara sehat. Pustakawan dapat mengoptimalkan perannya dalam memberikan sosialisasi kepada pemustakanya.

Ketiga, membuat jargon yang membuat pustakawan semangat bekerja secara profesional dan berdedikasi tinggi. Pustakawan proaktif bermedia sosial dengan memperlihatkan keunggulan dan keunikan perpustakaan yang dikelolanya (misalnya: 
membuat poster ajakan tidak plagiat, mengadakan pameran karya inovatif pustakawan, menggelar berbagai lomba, menyelenggarakan event pekan literasi, dan ide kreatif lainnya).

Terkait hasil kajian dalam ranah perpustakaan perguruan tinggi, Dickson \& Holley (2010) menyebutkan bahwa jejaring sosial adalah efektif. Hal ini mampu menyediakan informasi, menjangkau mahasiswa, dan menghargai privasinya. Jadi asumsi penulis bahwa pustakawan di berbagai jenis perpustakaan, dapat kreatif mengelola akun perpustakaannya dengan lebih variatif dan profesional. Upaya tersebut untuk meningkatkan kredibilitas pustakawan agar lebih profesional dalam menyikapi isu literasi informasi di era media sosial.

Infodemik dalam era media sosial ditandai dengan keberlimpahan informasi yang berlebihan yang kadang akurat dan kadang tidak. Infodemik menjadi informasi yang membingungkan masyarakat dan menimbulkan kerancuan informasi. Dalam konteks ini, berarti ada penyebaran berita bohong yang meresahkan sehingga muncul apa yang disebut dengan misinformasi, malinformasi, dan disinformasi. Misinformasi yaitu informasi yang tidak benar/salah yang sengaja disebarkan oleh orang yang mempercayainya sebagai hal yang benar. Tujuannya agar orang lain tertipu dan menganggap informasi tersebut adalah benar. Jika malinformasi diartikan sebagai informasi berdasarkan kenyataan tetapi digunakan untuk merugikan orang lain, sedangkan disinformasi berarti informasi tidak benar/salah yang tidak sengaja tersebar oleh orang yang mengetahui ketidakbenarannya.

Infodemik dalam suasana pandemi Covid-19 membahayakan masyarakat secara luas. Hoaks menjadi semakin marak dan justru dianggap suatu kebenaran. Hal ini diakibatkan oleh segregasi digital maupun sesuai dengan suara yang bergema saja. Jadi cerdas menghadapi informasi yang tidak jelas menjadi aspek kunci. Hubungan antara infodemik Covid-19, hoaks, maupun fake news yang beredar di media sosial dengan tupoksi pustakawan, memang tidak ada dalam petunjuk teknis (juknis). Namun setidaknya, pustakawan merupakan profesi yang berdekatan dengan sumber informasi, sehingga memiliki tanggung jawab moral dalam mengoptimalkan peran luasnya. Paling tidak memberikan edukasi (pendidikan pemustaka) kepada masyarakat tentang strategi melawan dan menangkal informasi yang tidak benar. Pustakawan bisa berkontribusi sebagai pegiat literasi dengan memberikan pemahaman kepada masyarakat, misalnya bagaimana mengakses informasi sehat dan cara menyikapi apabila memperoleh informasi yang meragukan. 


\section{E. KESIMPULAN}

Kompetensi literasi informasi dibutuhkan untuk menangkal infodemik. Sarana komunikasi melalui media sosial memudahkan interaksi sosial. Pustakawan dapat memanfaatkan sebagai media komunikasi dengan pemustaka dan promosi perpustakaan. Beredarnya infodemik Covid-19, hoaks, maupun fake news yang sangat masif beredar di media sosial memantik pustakawan agar memiliki keunggulan kompetensi literasi informasi. Sekalipun pustakawan tidak secara langsung bergelut dengan itu, tetapi pustakawan merupakan profesi yang sangat dekat dengan pengelolaan sumber informasi, koleksi ilmiah, dan diseminasi pengetahuan.

Solusinya pustakawan membutuhkan strategi kunci agar memiliki kompetensi literasi informasi dan langkah konkrit di era media sosial. Selain itu, pustakawan juga harus memperhatikan etika fundamental sehingga bijak dalam bermedia sosial. Kompetensi literasi informasi pustakawan membutuhkan daya kritis dalam memilah dan memilih maupun menyaring informasi yang berkelindan di media sosial, sehingga menghasilkan informasi yang bisa dipertanggungjawabkan. Agar pustakawan mampu berinternet sehat di era media sosial, maka harus bijak dan cerdas dalam merespon dan memanfaatkan media sosial.

Hubungan profesi pustakawan dengan informasi di media sosial adalah terkait dengan peran luas pustakawan dan kontribusinya di masyarakat dalam memberikan edukasi memanfaatkan media sosial. Strategi pustakawan dibutuhkan dalam melawan infodemik. Kompetensi literasi informasi pustakawan dibutuhkan mulai dari ketika menerima informasi. Prosesnya adalah dengan memahami, menganalisis, menyaring, menafsirkan makna, kemudian mengevaluasi informasi.

\section{DAFTAR PUSTAKA}

Casey, L., \& Bruce, B. C. (2011). The Practice Profile of Inquiry: Connecting Digital Literacy and Pedagogy. E-Learning and Digital Media, 8(1), 76-85. doi: http://dx.doi.org/10.2304/elea.2011.8.1.76.

Castiglione, D., Deth, J.W., \& Wolleb, G. (2008). Social Capital's Fortune: An Introduction. Dalam The Handbook of Social Capital. Oxford: Oxford University Press.

Cinelli, et al. (2020). The COVID-19 Social Media Infodemic. Scientific Reports (10), Article number: 16598.

Diamandis, P.H. and Kotler, S. (2012). Abundance: The Future Is Better You Think. New York: Free Press.

Dickson, A. \& Holley, RP., (2010). Social Networking in Academic Libraries: The Possibilities and The Concerns, New Library World, 111(11/12), 468-479. DOI:http://dx.doi.org/10.1108/03074801011094840.

Digital 2020: Indonesia. Diakses pada tanggal 3 Agustus 2020 dari https://datareportal.com/reports/digital2020-indonesia.

Eysenbach, G. (2000). How to Fight an Infodemic: The Four Pillars of Infodemic Management. J Med Internet Res 2020: 22(6):e21820) doi: 10.2196/21820. 
Fatmawati, E. (2017). Dampak Media Sosial Terhadap Perpustakaan. LIBRARIA: Jurnal Ilmu Perpustakaan, 5(1), 1-28. DOI: http://dx.doi.org/10.21043/libraria.v5i1.2250.

Fatmawati, E. (2018). Kompetensi Literasi Informasi Sebagai Strategi Kunci Berinternet Sehat di Era Media Sosial. Karya Tulis Dalam Lomba di Universitas Slamet Riyadi Surakarta.

Hilbert, M. (2012). How Much Information is There in the "Information Society"?. Significance, 9(4), 8-12.

Kaplan, AM. \& Haenlein, M. (2010). Users of The World, Opportunities of Social Media, Business Horizons, 53, 59-68. Tersedia di https://www.slideshare.net/escpexchange/kaplan-haenlein-users-of-the-worldunite-the-challenges-and-opportunities-of-social-media

Keyes, R. (2004). The Post-Truth Era: Dishonesty and Deception in Contemporary Life. New York: St. Martin's Press.

Lievrouw, LA., \& Livingstone, S. (2006). Handbook of New Media. Los Angeles: Sage Publications.

Mayfield, A. (2008). What is Social Media? Tersedia di http://www.icrossing.com/uk/sites/default/files_uk/insight_pdf_files/What\%20is\%20Social\%20Media_iC rossing_ebook.pdf

Nichols, T. (2017). The Death of Expertise: The Campaign Against Established Knowledge and Why it Matters. New York: Oxford University Press.

Paramita, R.P. (2020). Infodemi Memperburuk Dampak Pandemi Covid-19. Tersedia di https://lokadata.id/artikel/infodemi-memperburuk-dampak-pandemi-covid-19).

Perpustakaan Nasional RI. (2012). Keputusan Menteri Tenaga Kerja dan Transmigrasi RI Nomor 83 Tahun 2012 Tentang Penetapan Rancangan Standar Kompetensi Kerja Nasional Indonesia Sektor Jasa Kemasyarakatan, Sosial Budaya, Hiburan dan Perorangan Lainnya Bidang Perpustakaan Menjadi Standar Kompetensi Kerja Nasional Indonesia. Jakarta: Perpustakaan Nasional RI.

Perpustakaan Nasional RI. (2019). Keputusan Menteri Ketenagakerjaan Republik Indonesia Nomor 236 Tahun 2019 Tentang Penetapan Standar Kompetensi Kerja Nasional Indonesia Kategori Kesenian, Hiburan dan Rekreasi Golongan Pokok Perpustakaan, Arsip, Museum dan Kegiatan Kebudayaan Lainnya Bidang Perpustakaan. Jakarta: Perpustakaan Nasional RI.

Raacke, BJ. (2008). MySpace and Facebook: Applying the Uses and Gratifications Theory to Exploring Friend-Networking Sites. Journal of CyberPsychology \& Behavior, 11(2), 169-174. DOI: 10.1.1.453.8866\&rep=rep1\&type $=$ pdf

Shao, X., \& Purpur, G. (2016). Effects of Information Literacy Skills on Student Writing and Course Performance. The Journal of Academic Librarianship, 42(6), 670-678. doi:10.1016/j.acalib.2016.08.006.

Thurau, TH., et al. (2004). Electronic Word of Mouth via Consumer-Opinion Platforms: What Motivates Consumers to Articulate Themselves on the Internet? Journal of Interactive Marketing, 18(1), 38-52. Tersedia di https://doi.org/10.1002/dir.10073.

Tzanakis, M. (2013). Social Capital in Bourdieu's, Coleman's and Putnam's Theory: Empirical Evidence and

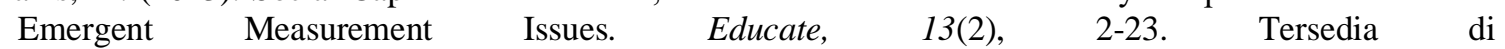
http://www.educatejournal.org/index.php/educate/article/download/366/293

Wasike, J. (2013). Social Media Ethical Issues: Role of a Librarian, Library Hi Tech News, 30(1), 8-16. DOI: http://dx.doi.org/10.1108/07419051311320922.

World Health Organization. (2020). Novel Coronavirus(2019-nCoV) Situation Report-13. Tersedia di https://www.who.int/docs/default-source/coronaviruse/situation-reports/20200202-sitrep-13-ncovv3.pdf?sfvrsn=195f4010_6.

Xie, I. \& Stevenson, J. (2014). Social Media Application in Digital Libraries. Online Information Review, $38(4)$ $502-523$.

Tersedia $\mathrm{di}$ https://www.researchgate.net/publication/275115518_Social_media_application_in_digital_libraries. 